\section{AUTHOR INDEX \\ VOLUME 43, 2001}

Aardsma G. New Radiocarbon Dates for the Reed Mat from the Cave of the Treasure, Israel, 1247

Abe O. See Hideshima S, 473

Abe O. See Yamano H, 899

Abramova ZA. The Age of Upper Paleolithic Sites in the Middle Dnieper River Basin of Eastern Europe, 1077

Aerts-Bijma AT. Automatic AMS Sample Combustion and $\mathrm{CO}_{2}$ Collection, 293

Aerts-Bijma AT. See Lanting JN, 249

Agnon A. See Ken-Tor R, 1371

Albani A. See Zoppi U, 489

Albuquerque ALS. See Santos GM, 801

Alderliesten C. See van der Borg K, 751

Alekseev Y. A Chronology of the Scythian Antiquities of Eurasia (Based on New Archaeological and ${ }^{14} \mathrm{C}$ Data), 1085

Alexandrovskiy AL. Chronology of Soil Evolution and Climatic Changes in the Dry Steppe Zone of the Northern Caucasus, Russia, During the 3rd Millennium $B C, 629$

Alloway BV. See Santos GM, 239

Appleby PG. See Goodsite ME, 495

Ammerman AJ. See Zoppi U, 489

An Z. See Shen C, 671

Anderson R. See Gulliver P, 869

Aramaki T. Distribution of Radiocarbon in the Southwestern North Pacific, 857

Aravena R. See Pessenda LCR, 595

Argemi M. See Girbal J, 637

Arneth A. See Santos GM, 239

Arnold M. See Valladas H, 977

Arslanov KA. New Data on Chronology of LandscapePaleoclimatic Stages in Northwestern Russia During the Late Glacial and Holocene, 581; see also Muraki $\mathrm{Y}, 695$

Aurenche O. Proto-Neolithic and Neolithic Cultures in the Middle East Birth of Agriculture, Livestock Raising, and Ceramics: a Calibrated ${ }^{14} \mathrm{C}$ Chronology 12,500- 5,000 cal BC, 1191

Avisar D. The Source of the Yarkon Springs, Israel, 793; see also Koral H, 957

Avner U. Settlement Patterns in the Southern Levant Deserts During the 6th-3rd Millennia BC: A Revision Based on ${ }^{14}$ C Dating, 1203

Badylak S. See Hillegonds AJ, 305

Baosheng L. See Zhou W, 619

Barbetti M. See Lange T, 449; see also Bourke S, 1217

Bartolomei P. See Plastino W, 157

Beavan-Athfield N. Environmental Influences on Dietary Carbon and ${ }^{14} \mathrm{C}$ Ages in Modern Rats and Other Species, 7; Bomb Carbon as a Tracer of Dietary Carbon Sources in Omnivorous Mammals, 711

Belinskiy AB. See Alexandrovskiy AL, 629
Belitzky S. See Nadel D, 1167

Bella F. See Plastino W, 157

Bernaldo De Quiros F. See Valladas H, 977

Berstan R. See Stott AW, 191

Bhushan R. See Dutta K, 483

Bird MI. See Fifield LK, 1139

Bird MI. See Santos GM, 239

Bird MI. See Turney CSM, 45

Boaretto E. Dedication to Israel Carmi, xi. See also Nadel D, 1167

Bokovenko NA. See Alekseev AY, 1085

Boltrik Y. See Alekseev AY, 1085

Bonani G. Radiocarbon Dates of Old and Middle Kingdom Monuments in Egypt, 1297

Bondar M. See Wild EM, 1057

Bonsall C. See Cook GT, 453

Boromean V. See Cook GT, 453

Bourke S. The Chronology of the Ghassulian Chalcolithic Period in the Southern Levant: $\mathrm{New}{ }^{14} \mathrm{C}$ Determinations from Teleilat Ghassul, Jordan, 1217

Bowman D. Load Structure Seismites in the Dead Sea Area, Israel: Chronological Benchmarking with ${ }^{14} \mathrm{C}$ Dating, 1383

Braun E. Proto, Early Dynastic Egypt, and Early Bronze 1-11 of the Southern Levant: Some Uneasy ${ }^{14}$ C Correlations, 1279

Bronk Ramsey C. Development of the Radiocarbon Calibration Program, 355; "Wiggle Matching” Radiocarbon Dates, 381; see also Hodgins GWL, 209; Stott AW, 191

Brown L. Radiocarbon Age Profiles and Size Dependency of Mixing in Northeast Atlantic Sediments, 929

Bruce D. Spatial Variations of Radiocarbon in the Coastal Aquifer of Israel-Indicators of Open and Closed Systems, 783

Bruhn F. Chemical Removal of Conservation Substances by "Soxhlet" Type Extraction, 229; see also Nadeau MJ, 169

Bruins H. Near East Chronology: Towards an Integrative ${ }^{14}$ C Time Foundation, 1147; Radiocarbon Challenges Archaeo-Historical Time Frameworks in the Near East: The Early Bronze Age of Jericho in Relation to Egypt, 1321; see also Bowman D, 1383; van der Plicht J, 1155

Bryant C. Is Comparability of ${ }^{14}$ C Dates an Issue?: A Status Report on the Fourth International Radiocarbon Intercomprarison, 321; see also Walker MJC, 1007

Burr GS. Sample Preparation of Dissolved Organic Carbon in Groundwater for AMS ${ }^{14} \mathrm{C}$ Analysis, 183; see also McGeehin J, 255; McNichol AP, 313; Slusarenko IY, 425; Kuzmin YV, 477; Zhou W, 619; Kalish JM, 843; Povinec PP, 879

Burton M. The Chalcolithic Radiocarbon Record and its 
Use in Southern Levantine Archaeology, 1223

Butters TD. See Hodgins GWL, 209

Cabrera-Valdes V. See Valladas H, 977

Cachier H. See Valladas H, 977

Carmi I. From the Guest Editor, xiii; see also Bryant C, 321; Kacanski A, 642; Stiller M, 821; Nadel D, 1167; Avner U, 1203; Mazar A, 1333

Chappell J. See Santos GM, 239

Cheoun MK. Pretreatment of Iron Artifacts at SNU-AMS, 217; see also Kim JC, 163

Chernov SB. See Arslanov KA, 581

Chichagova O. See Kovda I, 603

Chlenova L. See Kovalyukh N, 1064

Christen JA. See Slusarenko IY, 425

Chugunov KA. See Dergachev VA, 417; see also Alekseev AY, 1085

Cione AL. Did the Megafauna Range to 4300 BP in South America?, 69

Clottes J. See Valladas H, 977

Cook AC. AMS Radiocarbon Dating of Ancient Iron Artifacts: A Carbon Extraction Method in Use at LLNL, 221

Cook GT. A Freshwater Diet-Derived ${ }^{14} \mathrm{C}$ Reservoir Effect at the Stone Age Sites in the Iron Gates Gorge, 453; see also Bryant C, 321; Gulliver P, 869; Brown L, 929; Alekseev AY, 1085

Coope GR. See Hodgins GWL, 199; see also Walker MJC, 1007

Courtney C. See Burr GS, 183

Cordeiro RC. See Santos GM, 801

Cremasco MM. See Zoppi U, 1049

Cresswell RG. See Turney CSM, 45

Crombe P. See Van Strydonck MJY, 977; see also Van Strydonck MJY, 987

Cross FM. See Rasmussen KL, 127

Cryer FH. See Rasmussen KL, 127

Courtin J. See Valladas H, 977

Czernik J. Preparation of Graphite Targets in the Gliwice Radiocarbon Laboratory for AMS ${ }^{14}$ C Dating, 283

Davis PT. See McGeehin, 255

De Jong AFM. See van de Plassche, 391; see also van der Borg K, 751; Prins MA, 939

De Mulder G. See Van Strydonck MJY, 987

Dergachev VA. The Filling of Gaps in Geophysical Time Series by Artificial Neural Networks, 365; Dendrochronology and Radiocarbon Dating Methods in Archaeological Studies of Scythian Sites, 417; see also Alekseev AY, 1085

Deschieter J. See Van Strydonck MJY, 987

Di Tada ML. See Turney CSM, 45

Ditchburn RG. See Morgenstern U, 909

Donahue DJ. See Lange T, 449; see also Zhou W, 619

Doudna G. See Rasmussen KL, 127

Draxler S. See Wild EM, 1057

Druffel ERM. Changes of Subtropical North Pacific Ra- diocarbon and Correlation with Climate Variability, 15

Duhr A. See Bruhn F, 229; see also Nadeau M-J, 169

Dumke I. See Suckow A, 325

Dutta K. $\Delta R$ Correction Values For the Northern Indian Ocean, 483

Edwards RJ. See van de Plassche O, 391

Eine GL. See Kalish JM, 843

Elmore D. See Hillegonds AJ, 305

Enzel Y. See Frumkin A, 1179; see also Ken-Tor R, 1371

Eronen M. See Ogurtsov MG, 439

Evershed P. See Stott AW, 191

Evin J. See Aurenche O, 1191

Eyal Y. See Frumkin A, 1179

Facorellis Y. The Cave of Theopetra, Kalambaka: Radiocarbon Evidence for 50,000 Years of Human Presence, 1029

Fifield LK. Radiocarbon Dating of the Human Occupation of Australia Prior to $40 \mathrm{ka} \mathrm{BP}$-Successes and Pitfalls, 1139; see also Turney CSM, 45; Santos GM, 239; Santos GM, 801

Figini AJ. See Cione AL, 69

Flexer A. See Kacanski A, 647

Fortea-Perez JJ. See Valladas H, 977

Francesco B. See Plastino W, 157

Friedmann GM. See Bruce D, 783

Friesinger H. See Wild EM, 1057

Frumkin A. Radiocarbon Chronology of the Holocene Dead Sea: Attempting a Regional Correlation, 1179

Fulcher E. See Zoppi U, 1049

Fuls A. See Vogel JC, 133

Galet P. See Aurenche O, 1191

Gallagher D. A Recent History of ${ }^{14} \mathrm{C},{ }^{137} \mathrm{Cs},{ }^{210} \mathrm{P}_{b}$, and ${ }^{241} A_{m}$ Accumulation at Two Irish Peat Bog Sites: An East Versus West Coast Comparison, 517

Gambari FM. See Zoppi U, 1049

Gambari MV. See Zoppi U, 1049

Gavin DG. Estimation of Inbuilt Age in Radiocarbon Ages of Soil Charcoal for Fire History Studies, 27

Geyh MA. Bomb ${ }^{14}$ C Dating of Animal Tissues and Hair, 723; see also Morgenstern U, 909

Gilboa A. Early Iron Age Radiometric Dates from Tel Dor: Preliminary Implications for Phoenicia, and Beyond, 1343

Girbal J. Dating of Biodeposits of Oxalates at the Arc de Bera in Tarragone, Spain, 637

Gomes PRS. See Santos GM, 801

Gonzales-Sainz C. See Valladas H, 977

Goodsite ME. High-Resolution AMS ${ }^{14}$ C Dating of Post Bomb Peat Archives of Atmospheric Pollutants, 495

Gorban AN. See Dergachev VA, 365

Görsdorf J. New Radiocarbon Dates of the North Asian Steppe Zone and its Consequences for the Chronology, 
1115; Excavations at Ma'Layba and Sabir, Republic of Yemen: Radiocarbon Datings in the Period 1900 to 800 CAL BC, 1353; Radiocarbon Datings from the Almaqah Temple of Bar'an, Ma'rib, Republic of Yemen: Approximately 800 CAL BC to 600 CAL AD, 1363

Goslar T. Searching Solar Periodicites in the Late Glacial Record of Atmospheric Radiocarbon, 339; Absolute Production of Radiocarbon an the Long-Term Trend of Atmospheric Radiocarbon, 743; see also Czernik J, 283; Pawlyta J, 831

Gosse J. See McGeehin J, 255

Gottdang A. Accelerator Mass Spectrometry at High Voltage Engineering Europa (HVEE), 149

Gouveia SEM. See Pessenda LCR, 595

Graham IJ. See Morgenstern U, 909

Griffin S. See Druffel ERM, 15

Grigorieva GV. See Abramova ZA, 1077

Grootes PM. See Nadeau M-J, 169; see also Bruhn F, 229

Guilderson TP. See Druffel ERM, 15

Gulliksen S. See Bryant C, 321

Gulliver P. Transport of Sellafield Derived ${ }^{14} \mathrm{C}$ from the Irish Sea Through the North Channel, 869

Guo Z. See Lu X, 55

Guo Z. AMS Radiocarbon Dating of Tianma-Qucun Site in Shanxi, China, 1109

Haas, H See Bonani G, 1297

Halas S. See Pawlyta J, 831

Hansen TS. See Goodsite ME, 495

Hase Y. See Okuno M, 703

Hatté C. Is Classical Acid-Alkali-Acid Treatment Responsible for Contamination? An Alternative Proposition, 177; Development of Accurate and Reliable ${ }^{14} \mathrm{C}$ Chronologies for Loess Deposits: Application to the Loess Sequence of Nussloch (Rhine Valley, Germany), 611

Harada N. See Uchida M, 949

Harkness DD. See Bryant C, 321; Walker MJC, 1007

Hausladen PA. See Turney CSM, 45; Fifield LK, 1139; Santos GM, 239; Santos GM, 801

Hawass Z. See Bonani G, 1297

Head J. See Zhou W, 619

Hedges REM. The Future of the Past, 141; see also Stott AW, 191; Hodgins GWL, 199; Hodgins GWL, 209; Cook GT, 453

Heinemeier J. See Bryant C, 321; Goodsite ME, 495; Nadel D, 1167

Herut B. See Sivan O, 765; Yechieli Y, 773

Hideshima S. Northwest Pacific Marine Reservoir Correction Estimated from Annually Banded Coral from Ishigaki Island, Southern Japan, 473

Hillegonds AJ. PRIME Lab Sample Handling and Data Analysis for Accelerator-Based Biomedical Radiocarbon Analysis, 305

Hirota M. See Yoneda M, 465; Uchida M, 949

Hiyama T. See Takahashi HA, 659

Hodgins GWL. Protocol Development for Purification and Characterization of Sub-Fossil Insect Chitin for Stable Isotopic Analysis and Radiocarbon Dating, 199; The Chemical and Enzymatic Hydrolysis of Archaeological Wood Cellulose and Monosaccharide Purification by High Ph Anion Exchange Chromatography for Compound-Specific Radiocarbon Dating, 209

Hongji M. See Guo Z, 1109

Hua Q. Process in Radiocarbon Target Preparation at the Antares AMS Centre, 275; see also Zoppi U, 489; Zoppi U, 1049; Bourke S, 1217

Humm MJ. See Stott AW, 191

Ivy-Ochs S. Can We Use Cosmogenic Isotopes to Date Stone Artifacts?, 759

Jackson GS. See Hillegonds AJ, 305

Jacobsen GE. See Hua Q, 275

Jahn BM. See Rossello EA,77

Jeffrey D. See Burr GS, 183

Jinglin Y. See Guo Z, 1109

Jones M. Reservoir Offset Models for Radiocarbon Calibration, 119

Jull AJT. See Burr GS, 183; McGeehin, 255; McNichol AP, 313; Kuzmin YV, 477; Zhou W, 619; Lal D, 731; Povinec PP, 879

Jungner H. See Sonninen E, 271; Vasil'chuk YK, 527

Kacanski A. Late Holocene Climatic Change in the Balkans: Speleothem Isotopic Data from Serbia, 647

Kadan G. See Frumkin A, 1179

Kaihola L. See Plastino W, 157

Kalish JM. A Time History of Pre- and Post-Bomb Radiocarbon in the Barents Sea Derived from Arcto-Norwegian Cod Otoliths, 843

Kang J. See Kim JC, 163; Cheoun MK, 217; Yoshioka N, 555

Karimova LM. See Dergachev VA, 365

Kashgarian M. See Druffel ERM, 15

Kato M. See Muraki Y, 695

Kaufmann A. See Bruce D, 783; Stiller M, 821

Kaup E. See Olsson IU, 809

Kawamura K. See Uchida M, 949

Keally CT. See Kuzman YV,1121

Ken-Tor R. Precision of Calibrated Radiocarbon Ages of Historic Earthquakes in the Dead Sea Basin, 1371

Kershaw AP. See Turney CSM, 45

Kexin L. See Guo Z, 1109

Khokhlova OS. See Alexandrovskiy AL, 629

Kim IC. See Kim JC, 163; Cheoun MK, 217

Kim JC. Progress at the Seoul National University AMS Facility, 163; see also Cheoun MK, 217; Vasil'chuk YK, 1541

Kitagawa H. See Hideshima S, 473; Yamano H, 899

Klein M. See Gottdang A, 149

Klimanov VA. See Arslanov KA, 581

Knox FB. Least-Squares Fitting Smooth Curves to Dec- 
adal Radiocarbon Calibration Data from AD 1145 to AD 1945, 87

Kocharov GE. See Ogurtsov MG, 439

Kolton J. See Avisar D, 793

Konohira E. See Takahashi HA, 659

Konomatsu M. See Okuno M, 703

Koral H. Major Recent Tectonic Uplift in Iskenderun Bay, Turkey, 957

Kovalykh N. Dating of Ancient Icons from Kiev Art Collections, 1064; see also Alekseev AY, 1085

Kovda I. Radiocarbon Age of Vertisols and its Interpretation Using Data on Gilgai Complex in the North Caucasus, 603

Krapiec M. See Pazdur A, 403

Kronfeld J. See Weinstein-Evron M, 561; Kacanski A, 647; Avisar D, 793; Koral H, 957

Kruk RW. See Prins MA, 939

Kuandykov AE. See Dergachev, 365

Kubik PW. See Ivy-Ochs S, 759

Kudrass HR. See Morgenstern U, 909; Suckow A, 917

Kuji T. See Aramki T, 857

Kumamoto Y. See Uchida M, 949

Kusakabe M. See Uchida M, 949

Kutschera W. See Vasil'chuk YK, 541; Wild EM, 1057

Kuzmin YV. Radiocarbon Reservoir Correction Ages in the Peter the Great Gulf, Sea of Japan, and Eastern Coast of the Kunashir Kuriles (Northwestern Pacific), 477; Radiocarbon Chronology of the Earliest Neolithic Sites in East Asia, 1121; see also Slusarenko IY, 425

Kyparissi-Apostolika N. See Facorellis Y, 1029

Lacerela LD. See Santos GM, 801

Lal D. In-Situ Cosmogenic ${ }^{14}$ C: Production and Examples of its Unique Applications in Studies of Terrestrial and Extraterrestrial Process, 731

Lamers RAN. See van der Borg K, 751

Lang A. See Hatté C, 611

Lange T. Radiocarbon Measurements of Tree Rings from the Old Huon Pine, 449; see also Burr GS, 183; Goodsite ME, 495

Lanting JN. Dating of Cremated Bones, 249

Lawson EM. See Bourke S, 1121; Hua Q, 275; Zoppi U, 489; Hua Q, 1049

Lazar B. See Sivan O, 765; Yechieli Y, 773

Lee C. See Kim JC, 163

Lee JY. See Yoshioka T, 555

Lehner M. See Bonani G, 1297

Levy T. See Burton M,1223

Li K. See Guo Z,1109

Li Z. See Shen C, 671

Lindholm M. See Ogurtsov MG, 439

Lipschutz ME. See Hillegonds AJ, 305

Liu TK. See Rossello EA, 77

Liu T. See Shen C, 671

Liu X. See Guo Z, 1109

Lohse C. See Goodsite ME, 495
Lovell J. See Bourke S, 1217

Lowe JJ. See Walker MJC, 1007

Lu X. Data Analysis and Calibration of Radiocarbon Dating Results from the Cemetery of the Marquises of Jin, 55

Lynn W. See Kovda I, 603

Ma H. See Lu X, 55; Guo 1109

MacKenzie AB. See Gulliver P, 869; Brown L, 929

Maes A. See Van Strydonck MJY, 997

Makarenko NG. See Dergachev, 365

Maksimov FE. See Arslanov KA, 581

Maniatis Y. See Facorellis Y, 1029

Marco S. See Ken-Tor R, 1371; Nadel D, 1167

Masuda K. See Muraki Y, 695

Matsumoto E. See Hideshima S, 473

Mazar A. Radiocarbon Dates from Iron Age Strata at Tel Beth Shean and Tel Rehov, 1333

McFadgen BG. See Beavan-Athfield NR, 7; Knox FB, 87

McGann MJ. See Hua Q, 275

McGee EJ. See Bryant C, 321; Gallagher D, 517

McGeehin J. Stepped-Combustion ${ }^{14}$ C Dating of Sediment: A Comparison with Established Techniques, 255

McNichol AP. Converting AMS Data to Radiocarbon Values: Considerations and Conventions, 313

McSweeney K. See Cook GT, 453

Meijer HAJ. See Aerts-Bijma AT, 293

Michczynski A. See Pazdur A, 403

Mitchell PI. See Gallagher D, 517

Mintrop A. See Bruhn F, 229

Mintz G. See Stiller M, 821

Minami M. An Extraction System to Measure Carbon Terrestrial ages of Meteorites with a Tandetron AMS at Nagoya University, 263

Mizushima T. See Aramki T, 857

Mori Y. See Okuno M, 703

Morita M. See Yoneda M, 465; Uchida M, 949

Morgenstern U. ${ }^{32} \mathrm{Si}$ Dating of Marine Sediments from Bangladesh, 909; see also Suckow A, 917

Morvan J. See Hatté C, 177

Moure-Romanillo A. See Valladas H, 977

Mous DJW. See Gottdang A, 149

Muhs D. See McGeehin J, 255

Muller-Beck H. See Ivy-Ochs S, 759

Muraki M. See Uchida M, 949

Muraki Y. Measurement of Radiocarbon Content in Leaves from Some Japanese Sites, 695

Murata T. See Muraki Y, 695

Nadeau MJ. Carbonate ${ }^{14}$ C Background: Does it Have Multiple Personalities?, 169; see also Bruhn F, 229

Nadel D. New Dates From Submerged Late Pleistocene Sediments in the Southern Sea of Galilee, Israel, 1167

Nagaoka S. See Okuno M, 703

Nagler A. See Görsdorf J, 1115

Nagovitsyn YA. See Ogurtsov MG, 439 
Nakamura T, See Minami M, 263; Takahashi HA, 433; Takahashi HA, 659; Okuno M, 703; Yamano H, 899 Nakhla S. See Bonani G, 1297

Naruse Y. See Muraki Y, 695

Naysmith P. See Bryant C, 321; Gulliver P, 869

Nedreaas KH. See Kalish JM, 843

Negendank JF. See Ken-Tor R,1371

Nicholls G. See Jones M, 119

Niese S. The First Paper About Exciting of Fluorescence of Liquid Biphenyl and Phenanthren by Fast Electrons by Lieselott Herforth and Hartmut Kallmann, 125

Nishida T. See Okuno M, 703

Nishiyama T. See Muraki Y, 695

Niu E. See Yamano H, 899

Nolan J. See Bonani G, 1297

Noury C. See Hatté C, 177

Nydal R. See Kalish JM, 843

Oda H. See Nakamura T,1129

Oerlemans J. See van der Borg K, 751

Ogurtsov MG. Solar Activity and Regional Climate, 439

Ohkushi K. See Uchida M, 949

Okuno M. 5.2-5.8 KA BP Paleoenvironment of the Southern Slope of Mount Raizan, Japan, 703

Olsson IU. The Varying Radiocarbon Activity of Some Recent Submerged Estonian Plants Grown the Early 1990s, 809

Omoto K. Radiocarbon Age of Beachrocks and Late Holocene Sea-Level Changes in the Southern Part of the Nansei Islands, Southwest of Japan, 887

Ooi S. See Goodsite ME, 495

Oriwall A. See Nadeau M-J, 169

Orlova LA. See Slusarenko IY, 425

Ossowski W. See Pazdur A, 403

Park JH. See Kim JC, 163; Cheoun MK, 217

Parzinger H. See Görsdorf J, 1115

Paterne M. See Hatté C, 177; Tisnérat-Laborde N, 299; Goslar T, 339; Hatté C, 611

Paunovic M. See Wild EM, 1021

Pawełczyk S. See Rakowski A, 679

Pawlyta J. Influence of the Bomb-Produced ${ }^{14} \mathrm{C}$ on the Radiocarbon Concentration in the Youngest Sediment of Lake Gosciaz, Central Poland, 831

Pazdur A. Radiocarbon and Dendrochronological Dating of Logboats from Poland, 403; see also Rakowski A, 679; Pawlyta J, 831

Peng S. See Shen C, 671

Pessenda LCR. Radiocarbon Dating of Total Soil Organic Matter and Humin Fraction and its Comparison with ${ }^{14} \mathrm{C}$ Ages of Fossil Charcoal, 595; see also Hatté C, 611

Petchey FJ. Radiocarbon Determinations from the Mulifanua Lapita Site, Upolu, Western Samoa, 63

Petrocelli JL. See Rossello EA, 77

Pettitt PB. See Cook GT, 453

Pillans B. See Santos GM, 239
Plastino W. Cosmic Background Reduction in the Radiocarbon Measurements by Liquid Scintillation Spectrometry at the Underground Laboratory of Gran Sasso, 157

Ponomareva VV. See Zaretskaia NE, 571

Possnert G. See Bryant C, 321; Kovalyukh N, 1064; Alekseev AY, 1085

Poupeau JJ. See Tisnérat-Laborde N, 299

Povinec PP. Radiocarbon in Seawater at Radioactive Waste Dumping Sites in the Northwest Atlantic and Northwest Pacific, 879; see also Aramaki T, 857

Prada JL. See Girbal J, 637

Priller A. See Wild EM, 1057

Prins MA. The Late Quaternary Sedimentary Record on Reykjanes Ridge (North Atlantic), 939

Puchegger S. See Steier P, 373

Rabeder G. See Wild EM, 1021

Rakowski A. Changes of ${ }^{14} \mathrm{C}$ Concentration in Modern Trees from Upper Silesia Region, Poland, 679

Rank D. See Vasil'chuk YK, 541

Rasmussen KL. The Effects of Possible Contamination on the Radiocarbon Dating of the Dead Sea Scrolls I: Castor Oil, 127

Record R. See Hillegonds AJ, 305

Regagnon-Caroline E. See Aurenche O,1191

Reimer PJ. A Marine Reservoir Correction Database and On-Line Interface, 461

Reimer RW. See Reimer PJ, 461

Reines D. See Burr GS, 183; McGeehin J, 255

Rick TC. AMS Radiocarbon Dating of a Shell Fishhook from Santa Rosa Island, California, 83

Rickey FA. See Hillegonds AJ, 305

Rocabayera R. See Girbal J, 637

Rom W. See Steier P, 373; Goodsite ME, 495; Wild EM, 1057

Ronen D. See Yechieli Y, 773

Rosenthal E. See Avisar D, 793

Rossello EA. The 4300-yr ${ }^{14} \mathrm{C}$ Age of Gluptodonts at Lujan River (Mercedes, Buenos Aires, Argentina) and Comments on 'Did the Megafauna Range to 4300 BP in South America' by Cione et al., 77

Rossiev AA. See Dergachev, 365

Ruttkay E. See Wild EM, 1057

Santos GM. Radiocarbon Dating of Wood Using Different Pretreatment Procedures: Application to the Chronology of Rotoehu Ash, New Zealand, 239; Chronology of the Atmosphere Mercury in Lagoa da Plata Basin Upper Rio Negro Region of Brazilian Amazon, 811; see also Turney CSM, 45

Savage S. Towards an AMS Radiocarbon Chronology of Predynastic Egyptian Ceramics, 1255

Savelieva LA. See Arslanov KA, 581

Schuchter C. See Ivy-Ochs S, 759

Schrag DP. See Druffel ERM, 15

Scott EM. See Bryant C, 321; Walker MJC, 1007; Alek- 
seev AY, 1085

Sementsov AA. See Dergachev VA, 417; Alekseev AY; Serandrei Barbero R. See Zoppi U, 489

Sharon H. See Gilboa A, 1343

Sharon L. "Transition Dating"- A Heuristic Mathematical Approach to the Collation of Radiocarbon Dates from Stratified Sequences, 345

Shemesh A. See Kacanski A, 647

Shen C. Distribution of ${ }^{14} \mathrm{C}$ and ${ }^{13} \mathrm{C}$ in Forest Soils of the Dinghushan Biosphere Reserve, 671

Shibata Y. See Yoneda M, 465; Uchida M, 949

Shotyk W. See Goodsite ME, 495

Sifeddine A. See Santos GM, 801

Silva-Filho EV. See Santos GM, 801

Simmons-Byrd A. See Hillegonds AJ, 305

Sivan O. Radiocarbon Dating of Porewater-Correction for Diffusion and Diagenetic Process, 765; see Yechieli Y, 773

Skripkin V. See Kovalyukh N, 1064; Alekseev AY, 1085

Sljusarenko IJ. See Dergachev VA, 417

Slusarenko IY. ${ }^{14} \mathrm{C}$ Wiggle Matching of the "Floating" Tree-Ring Chronology from the Altai Mountains, Southern Siberia: The Ulandryk - 4 Case Study, 425

Smith AM. See Hua Q, 275

Smith DG. See Taylor RE, 965

Somayajulu BLK. See Dutta K, 483

Song YM. See Kim JC, 163; Cheoun MK, 217

Sonninen E. An Improvement in Preparation of Mortar for Radiocarbon Dating, 271

Southon JR. See Druffel ERM, 15; Cook AC, 221; McGeehin J, 225; Torn MS, 691; Taylor RE, 965

Sparks RJ. See Beavan-Athfield N, 7, 711

Steffan I. See Wild EM, 1021

Stadler P. See Wild EM, 1057

Steier P. New Methods and Critical Aspects in Bayesian Mathematics for ${ }^{14} \mathrm{C}$ Calibration, 373; see also Dergachev VA, 365; Wild EM, 1021, 1057

Stein M. See Ken-Tor R, 1371

Stiller M. Calibration of Lacustrine Sediment Ages Using the Relationships Between ${ }^{14} \mathrm{C}$ Levels in Lake Waters and in the Atmosphere: The Case of Lake Kinneret, 821

Strugnell J. See Rasmussen KL, 127

Stott AW. Radiocarbon Dating of Single Compounds Isolated from Pottery Cooking Vessel Residues, 191

Subetto DA. See Arslanov KA, 58

Suckow A. A Database System for Geochemical, Isotope Hydrological and Geochronological Laboratories, 325; Absolute Dating of Recent Sediments in the Cyclone-Influenced Shelf Area off Bangladesh: Comparison of Gamma Spectrometric $\left({ }^{137} \mathrm{Cs},{ }^{210} \mathrm{~Pb},{ }^{228} \mathrm{Ra}\right)$, Radiocarbon and ${ }^{32}$ Si Ages, 917

Sulerzhitsky LD. See Zaretskaia NE, 571

Sun Y. See Shen C, 671

Takahashi A. See Takahashi HA, 659

Takahashi HA. Seasonal Fluctuation of Stable Carbon
Isotopic Composition in Japanese Cypress Tree Rings from the Last Glacial Period-Possibility of Paleoenvironment Reconstruction, 433; Balance and Behavior of Carbon Dioxide at an Urban Forest Inferred from the Isotopic and Meteorological Approaches, 659; see also Yoshioka T, 555; Okuno M, 703

Tanka A. See Yoneda M, 465; Uchida M, 949

Taniguchi Y. See Nakamura T,1129

Tannau JF. See Tisnérat-Laborde N, 299

Taylor RE. The Kennewick Skeleton: Chronological and Biomolecular Contexts, 965

Tertychnaya TV. See Arslanov KA, 581

Thomas JM. See Burr GS, 183

Thomassen M. See van der Borg K, 751

Thomson J. See Brown L, 929

Thorpe JL. See Hodgins GWL, 199

Tisnérat-Laborde N. Development of a Semi-Automated System for Routine Preparation of Carbonate Samples, 299; see also Goslar T, 339; Valladas H, 977

Togawa O. See Aramaki T, 857

Tonni EP. See Cione AL, 69

Torn MS. A New ${ }^{13}$ C Correction for Radiocarbon Samples from Elevated-CO $\mathrm{C}_{2}$ Experiments, 691

Toyoizumi H. See Muraki Y, 695

Troelstra SR. See Prins MA, 939

Tsuji S. See Nakamura T,1129

Turcq B. See Santos GM, 801

Turney CSM. Development of a Robust ${ }^{14} \mathrm{C}$ Chronology for Lynch's Crater (North Queensland, Australia) Using Different Pretreatment Strategies, 45

Uchida M. Compound-Specific Radiocarbon Ages of Fatty Acids in Marine Sediments from the Western North Pacific, 949; see also Yoneda M, 465

Uzawa K. See Yoneda M, 465

Valladas H. Radiocarbon AMS Dates for Paleolithic Cave Paintings, 977

van de Plassche O. ${ }^{14} \mathrm{C}$ Wiggle-Match Dating in HighResolution Sea-level Research, 391

van der Borg K. IN-SITU Radiocarbon Production by Neutrons and Muons in an Antarctic Blue Ice Field at Scharffen Bergbotnen: A Status Report, 751; see also van de Plassche O, 391; Prins MA, 939

van der Kemp WJM. See van der Borg K, 751

van der Knapp WO. See Goodsite ME, 495

van der Plicht J. Radiocarbon Dating in Near-Eastern Contexts: Confusion and Quality Control, 1155; see also Rasmussen KL, 127; Lanting JN, 249; AertsBijma AT, 293; Bryant C, 321; Bronk-Ramsey C, 381; Alexandrovskiy AL, 629; Kovalyukh N, 1064; Alekseev AY, 1085; Bruins H, 1313, Bowman D, 1383

Van Strydonck M. Radiocarbon as Tool of Modeling the Diachronic Analysis of the Occupation Phases at the Velzeke Site (Belgium), 987; The Site of Verrebroek 'Dok' and its Contribution to the Absolute Dating of the Mesolithic in the Low Countries, 997; see also 
Bryant C, 321

van de Wal RSW. See van der Borg K, 751

Vasil'chuk AC. See Vasil'chuk YK, 527, 541

Vasil'chuk YK. ${ }^{14} \mathrm{C}$ Dating of Peat and $\delta^{18} O-\delta D$ in Ground Ice From North-West Siberia, 527; Radiocarbon Dating of $\delta^{18} O-\delta D$ Plots in Late Pleistocene IceWedges of the Duvanny Yar (Lower Kolyma River, Northern Yakuita), 541

Vasiliev SS. See Dergachev VA, 417; Alekseev AY, 1085

Vengosh A. See Yechieli Y, 773

Visser E. See Vogel JC, 133

Voelker A. See Nadeau M-J, 169

Vogel JC. Suitability of Ostrich Eggshell for Radiocarbon Dating, 133; see also Weinstein-Evron M, 561; Koral H, 957

Vogt B. See Görsdorf J, 1345, 1355

Wada H. See Takahashi HA, 433

Wadsworth J. See Cook AC, 221

Walker MJC. Towards a Radiocarbon Chronology of the Late-Glacial: Sample Selection Strategies, 1007

Weinberger G. See Avisar D, 793

Weinstein-Evron M. Further Attempts at Dating the Palynological Sequence of the Hula L07 Core, Upper Jordan Valley, Israel, 1007

Weninger B. See Bronk Ramsey C, 381

Wenke R. See Bonani G, 1297

Werker E. See Nadel D, 1167

Wild EM. Age Determination of Fossil Bones from the Vindija Neanderthal Site in Croatia, 1021; New Chronological Frame for the Young Neolithic Baden Culture in Central Europe (4th Millennium BC), 1057

Williams AA. See Hua Q, 275

Williams D. See Kovda I, 603

Wölfli W. See Bonani G, 1297

Wu X. See Lu X, 55; Guo Z, 1109

Wust R. See Ivy-Ochs S, 759
Xiangyang L. See Guo Z, 1109

Xing C. See Shen C, 671

Xu L. See Guo Z, 1109

Yam R. See Kacanski A, 647

Yamano H. Coral Reef Evolution at the Leeward Side of Ishigaki Island, Southwest Japan, 899

Yang Y. See Shen C, 671

Yanko V. See Koral H, 957

Yechieli Y. ${ }^{14} \mathrm{C}$ Seawater Intruding into the Israeli Mediterranean Coastal Aquifer, 773; see also Sivan O, 765; Bruce D, 783

Yi W. See Shen C, 671

Yoneda M. Marine Radiocarbon Reservoir Effect in the Western North Pacific Observed in Archaeological Fauna, 465; see also Uchida M, 949

Yonenobu H. See Takahashi HA, 433

Yoshida N. See Takahashi HA, 659

Yoshioka T. Paleoenvironment in Dae-Am San High Moor in the Korean Peninsula, 555

Youping Z. See Turney CSM, 45

Yuan C. See Shen C, 671

Yuan S. See Lu X, 55; Guo Z, 1109

Zaitseva GI. See Dergachev VA, 417; Abramova ZA, 1077; Alekseev AY, 1085

Zaretskaia NE. Radiocarbon Studies of Peat Bogs: An Investigation of South Kamcharka Volcanoes and Upper Volga Archeological Sites, 571

Zhengkun W. See Zhou W, 619

Zhilin MG. See Zaretskaia NE, 571

Zhou W. Environmental and Climatic Change as Recorded in Geological Sediments from the Arid to SemiArid Zone of China, 619

Zoppi U. Preliminary Estimate of the Reservoir Age in the Lagoon of Venice, 489; The Copper Age in Northern Italy, 1049; see also Hua Q, 275; Bourke S, 1217 